WIDER Working Paper 2016/178

\title{
A review of social issues for biofuels investment in Mozambique
}

Emílio Tostão, ${ }^{1}$ Giles Henley, ${ }^{2}$ Joel Tembe, ${ }^{3}$ and Aristides Baloi ${ }^{3}$

December 2016 
Abstract: This study discusses the potential for expanding cultivation of biofuel feedstock in Mozambique from several angles. Taking the case of sugarcane, it explores the potential to expand production, through exploring both biophysical factors and patterns of existing investment. We review recent literature on trends in land allocation and practices of resettlement in Mozambique to highlight opportunities and constraints that current plans for biofuel production should consider. While resource availability suggest opportunities exist to expand cultivation, minimizing social risks when doing so depends on the processes followed to transfer land from existing users, and compensation in the short and long term.

Keywords: biofuels, Mozambique, sugarcane

JEL classification: 013, Q10

Acknowledgements: We are grateful for inputs from Channing Arndt and colleagues working on the Biofuels component of UNU-WIDER's 'Regional growth and development in Southern Africa' project. All errors and omissions are our own.

1 Centro de Estudos de Políticas e Programas Agroalimentares (CEPPAG), Universidade Eduardo Mondlane, Maputo, Mozambique; ${ }^{2}$ Overseas Development Institute, London, UK, corresponding author: g.henley@odi.org.uk; ${ }^{3}$ Universidade Eduardo Mondlane, Maputo, Mozambique.

This study has been prepared within the UNU-WIDER project on 'Inclusive growth in Mozambique — scaling up research and capacity'.

Copyright (C) UNU-WIDER 2016

Information and requests: publications@wider.unu.edu

ISSN 1798-7237 ISBN 978-92-9256-222-9

Typescript prepared by Sophie Richmond.

The United Nations University World Institute for Development Economics Research provides economic analysis and policy advice with the aim of promoting sustainable and equitable development. The Institute began operations in 1985 in Helsinki, Finland, as the first research and training centre of the United Nations University. Today it is a unique blend of think tank, research institute, and UN agency - providing a range of services from policy advice to governments as well as freely available original research.

The Institute is funded through income from an endowment fund with additional contributions to its work programme from Denmark, Finland, Sweden, and the United Kingdom.

Katajanokanlaituri 6 B, 00160 Helsinki, Finland

The views expressed in this paper are those of the author(s), and do not necessarily reflect the views of the Institute or the United Nations University, nor the programme/project donors. 


\section{Introduction}

\subsection{Motivation}

The motivation of this study is to explore the potential for Mozambique to ramp up its production of biofuel feedstocks to fuel a domestic and regional market. The latter is discussed elsewhere in this series.

The first aim is to provide an overview of what areas of the country are suitable for the cultivation of sugarcane, which is already a well-established and important crop in Mozambique and would be the crop of choice for a future biofuels industry in Mozambique. We do this by analysing recent information on biophysical characteristics of different parts of the country to identify areas of high, medium, and low suitability.

The second aim of the paper is to qualify the biophysical approach through supplementary analysis of social constraints associated with expansion of agriculture investments. While the biophysical mapping approach can provide important information on area and location for prioritization, it reveals little about the social opportunities and constraints to putting land under sugarcane. While at least one previous land-use mapping study (van der Hilst and Faaij 2012) has incorporated social issues into calculations of available land by excluding areas that may be subject to existing claims, there is a need to update understanding with discussion of what constitutes land availability.

\section{Methodology}

There have been several previous exercises that aimed to establish suitable areas for biofuels production. A land-use study was carried out by the government of Mozambique (IIAM and DNTF 2008), which, while providing some information, has been criticized for its use of outdated rainfall data and the fact that the scale was too large to be useful. A study by Schut et al. (2010) also looked at social and economic factors, but discussed these in terms of population density, literacy, enrolment in education, access to improved inputs, and agronomic advice. The most comprehensive study (van der Hilst et al. 2012) identified areas suitable for biofuel investments through looking at a wide range of factors, including costs derived from transport. This also excluded areas for which there were existing land claims from specific groups, including farmers, pastoralists, communities, and investors. However, no more recent studies have been carried out since data on the land rush emerged, and none have integrated discussion on the social impacts of investment, for which there is now new data.

To shed some light on these issues, we review recent evidence on the establishment of large farms from several types of literature and data sources. This includes recent surveys of large farms, including current land use, and the processes that have been used to establish them. We also review recent literature on approaches to and experiences of integrating neighbouring communities and resettling households as part of transferring land to large farms in order to shed light on the social opportunities and constraints.

\subsection{Identification of suitable land for sugarcane}

To identify areas with suitable agro-ecological characteristics, we overlaid biophysical data using mapping software. We used ArcGIS 20.2.1 for mapping and combination of factors, and Microsoft Excel to generate a pairwise comparison matrix of factors. The data used includes: (1) data on precipitation and temperature from 2005 to 2009 from the National Institute of Meteorology 
(INAM); (2) data from ASTER (Advanced Space-borne Thermal Emission and Reflection Radiometer) from 2011, with an adequate resolution to produce a slope map and identify sites with flatter slopes and steep slopes, since this influences the velocity of water flow; (3) soil data, to identify soils with low, medium, and higher permeability, as soil permeability may influence sugarcane production; (4) apart from data on land use (from CENACARTA), ${ }^{1}$ multi-criteria analyses (data combination) were developed in SIG environment ArcGIS software with Arc Map extension via cartographic algebra, to simplify the treatment and crossing data. We then discuss social constraints on investment by looking at processes of previous investment and delimitation of community land.

In addition, we carried out a review of legislation, recent policies, and recent literature on biofuels. Documents reviewed included policies, regulations and policy studies such as:

- biofuel strategy and policy

- renewable energy strategy

- environmental impact assessment regulation

- resettlement regulation.

Finally, we carried out key informant interviews with stakeholders in the districts of Manhiça, Magude, Chokwé, and Massingir.

\subsection{Methodological issues}

Publicly available data on Direito de Uso e Aproveitamento dos Terras (DUATs) that have been awarded is incomplete. A recent exercise to compile information on DUATs (Di Matteo and Schoneveld 2016) between 2008 and 2012 was only able to obtain full and reliable information on 32 per cent (159) of investments in the agriculture sector. This was achieved by pulling together information from national and provincial offices; most of the latter were not willing to provide data on DUATs.

\section{Background}

\subsection{The rural sector in Mozambique}

\section{Rural sector performance}

Although around 80 per cent of Mozambique's population works in agriculture, the sector performs poorly and accounts for around 20 per cent of gross domestic product (GDP) and is a major reason why poverty rates continue to be high (Arndt et al. 2012). Mozambique has 80 million hectares (ha) of land, of which 36 million ha (or 45 per cent) is arable; 5.8 million ha is estimated to be under cultivation, and a further 9.2 million ha is used for livestock production. Of the area under cultivation, 5.5 million ha, or 95 per cent of the total area, is cultivated by smallholders with between 0.1 and 1 ha of land, who make up 99.8 per cent of all farms in Mozambique.

Despite years of intervention by government and development partners in the sector, there has been little progress in improving levels of productivity of most crops smallholder farmers cultivate

\footnotetext{
${ }^{1}$ See: http://www.cenacarta.com/
} 
(Figure 1), in part because access to input and output markets have not improved (Inquérito Agrícola Integrado [IAI] data reported in Deininger and Xia 2016).

Figure 1: Yields for major agriculture crops in Mozambique (2002-14)

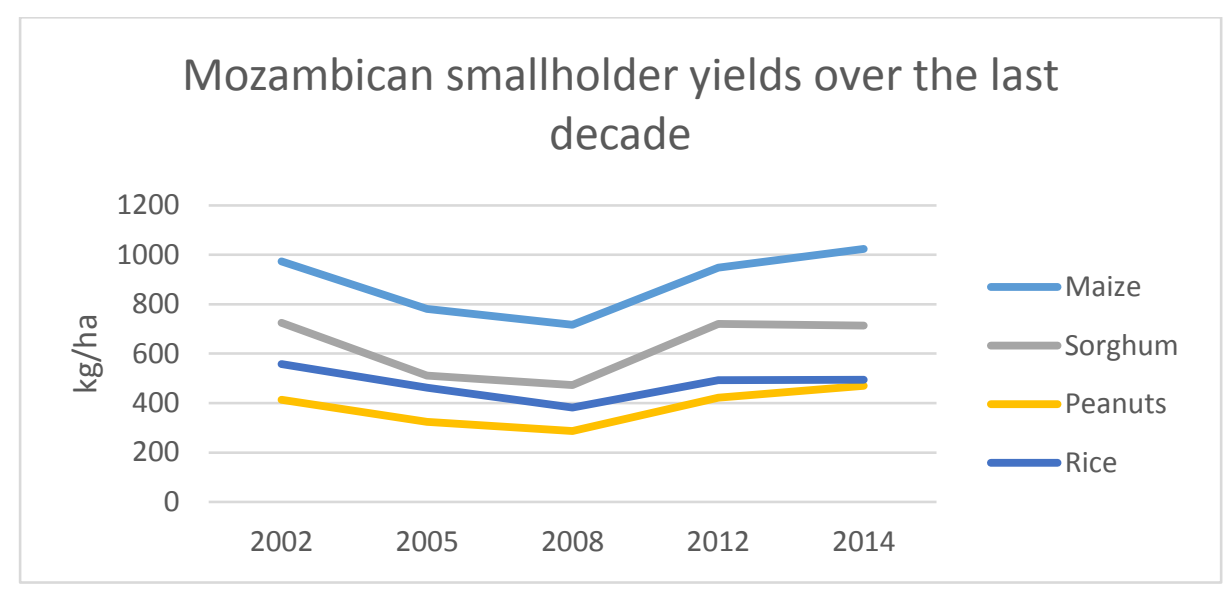

Source: Authors' compilation based on IAI data reported in Deininger and Xia (2016).

Opportunities in the rural off-farm sector also remain limited, with households participating in formal and informal sales of goods from household industries, quarrying and construction, and other extractive activities such as fishing (especially for women). ${ }^{2}$

\section{Food insecurity}

Food insecurity and malnutrition remain high in much of rural Mozambique. Indicators suggesting malnutrition is high and has severe implications for public health, including: (1) a mortality rate of 87 under-5-year-olds per 1,000 live births, affecting their mental, physical, and cognitive potential; (2) small stature, low physical productivity capacity, which affects most international commitments intended to bring about socioeconomic development in the country (Government of Mozambique 2010).

Data on malnutrition in Mozambique show that over 50 per cent of the population suffer from the effects of chronic malnutrition. This is higher in rural areas at 50 per cent. Although chronic malnutrition of under-5-year-olds decreased from 48 per cent in 2003, it remains high at around 43 per cent in 2011 (UNICEF 2016). Over 40 per cent of people are stunted and provinces with higher levels ( $>50$ per cent) include Cabo Delgado and Nampula, while Zambezia, Niassa, and Tete have an intermediate rate of $(>45$ per cent). Three provinces have a lower rate ( $<45$ per cent) including Inhambane, Maputo, and Gaza.

At the time of research (mid-2016), almost all districts in southern Mozambique faced food insecurity due to a prolonged drought that has affected the country for last two years. Most farmers rely on rain-fed farming and are unable to produce enough food. In the areas visited, most of silos are empty and farmers do not have reserves of cereals and rely on plants and crops usually fed to ruminants to complement their diets.

\footnotetext{
2 Field interviews in Massingir.
} 
The total area of land controlled by smallholders cultivating less than 10 ha by far exceeds landholding by other categories of farmers (Figure 2).

Figure 2: Breakdowns of total landholding area and cultivated area by farm size (2012)

\section{Total area under different-sized farms (ha) Total area cultivated (ha)}
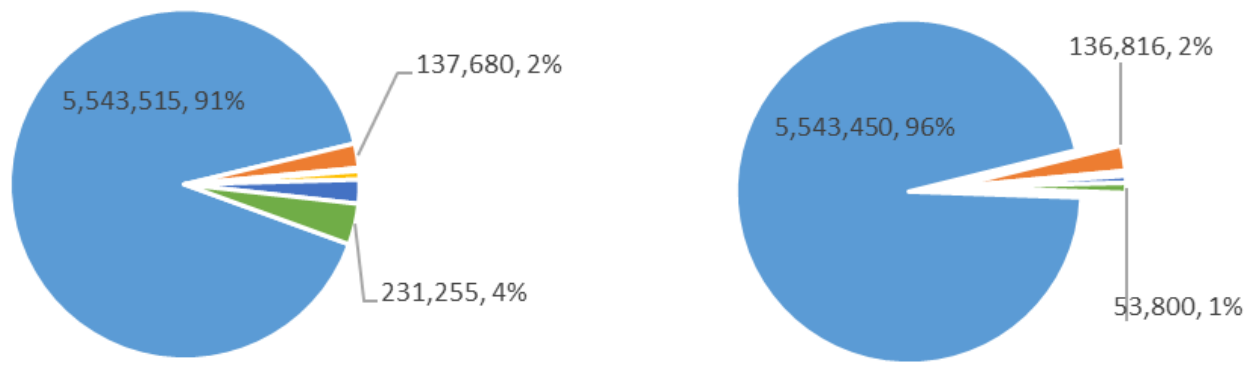

$$
\begin{aligned}
& =0.1-10 \text { ha }=10.1-50 \text { ha }=50.1-200 \text { ha } \\
& =200.1-1000 \text { ha }=1000.1-5000 \text { ha }=\text { above } 5,000 \text { ha }
\end{aligned}
$$

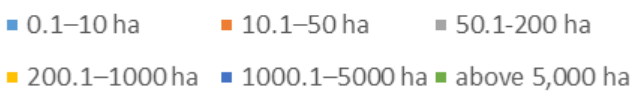

Source: IAI survey (2012) as reported in Deininger and Xia (2016).

In terms of crops under cultivation, smallholders with less than 10 ha predominantly grow maize, with average yields that are among the lowest in Africa (Deininger and Xia 2016), and with small areas planted to other crops, including pulses, cassava, and rice. Larger farmers grow less maize and pulses and more other (commercial) crops. Sugarcane is predominantly grown on farms larger than 1,000 ha and especially more than 5,000 ha (Figure 3).

Figure 3: Cultivation of crops by different size of farm-holding

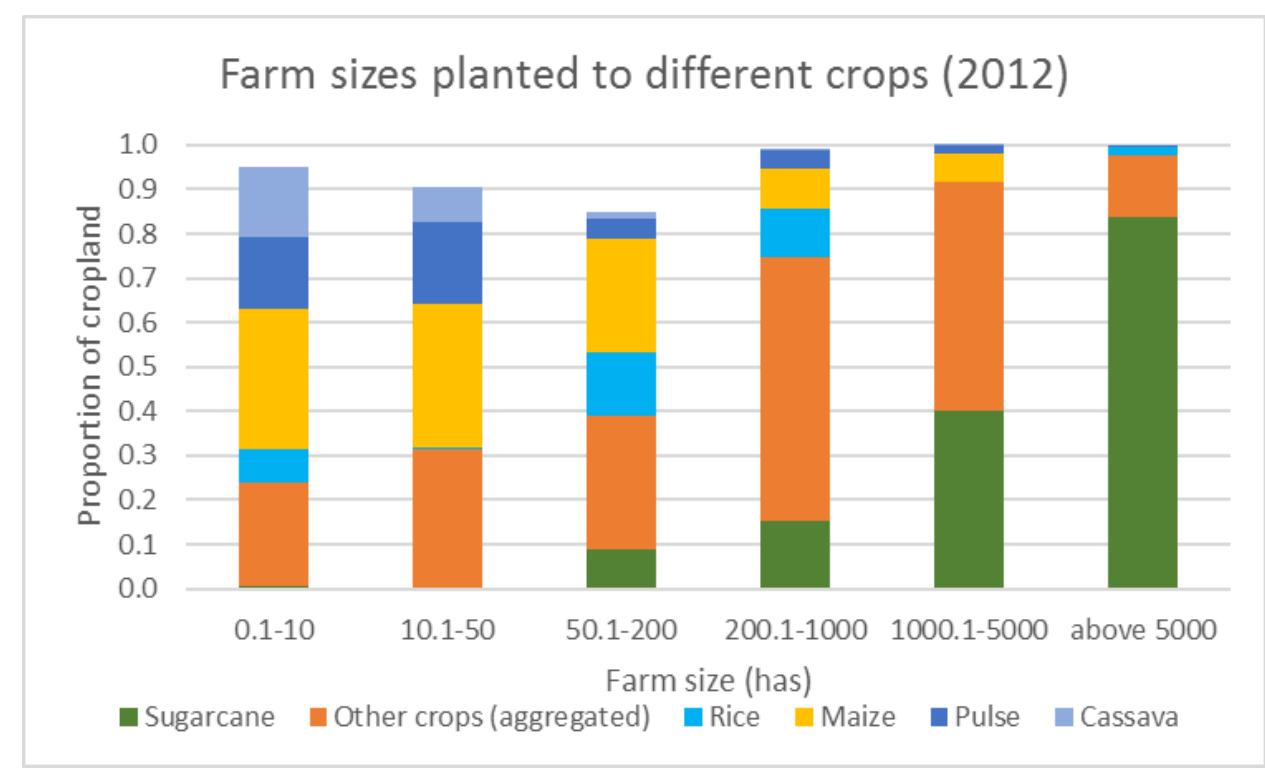

Source: IAI survey (2012) as reported in Deininger and Xia (2016).

However, the small number of large farms cover a relatively large proportion of land, much of which is fallow. Figures 1 and 2 show that although farms larger than 5,000 ha account for around 4 per cent of total farmland area, they only account for 1 per cent of the land under cultivation. 
This is discussed further below. The high level of unused land in farms of larger sizes is shown in Figure 3.

\subsection{Agricultural policy, investment, and biofuels in Mozambique}

Approach to agricultural policy

The current plan for rural development, the Strategic Plan for Agricultural Development (PEDSA) aims to expand the area of cultivation of food crops by 25 per cent by 2020 , and to strengthen cooperation between smallholders and the private sector across a number of value chains in priority corridors. The Mozambican government has taken a dualistic approach to promoting agriculture through support to both smallholders and to the development of large-scale commercial agriculture. The latter has been promoted through a series of policy measures, including the promotion of agricultural corridors, and by providing tax relief to large firms.

There has been long-standing support for the sugar sector, which, following the end of the civil war in the mid-1990s, was targeted for rehabilitation and benefited from significant investment from then on. This rebirth of the sugar industry is widely acclaimed as a success, with four out of the former six estates rehabilitated and employment in the sector reaching 40,000 jobs (Buur et al. 2012), making the sector the second largest employer after the government.

The government's openness to foreign investment made it one of the most attractive countries for foreign investment following the 2007-8 food price spike. Between 2004 and 2009, the government of Mozambique approved land concessions of more than 2.5 million ha. Between 2008 and 2012 the area of land concessions increased to 6.7 million ha. The rapid pace of investment, and uncertainty over whether institutions had the capacity to appraise project proposals and monitor their implementation, led the government to introduce a moratorium on land deals in 2009 which lasted until 2011. While concern over the high level of investment appeared to temper government enthusiasm for large investments, it appears that substantial volume of land acquisitions of smaller areas continued: requests for - and approval of DUATs for - large areas of land appear to have decreased from 2011 onwards (Cabral and Norfolk 2016). In terms of DUATs awarded, analysis of data on DUAT applications for 159 investments that have been requested and approved suggests that around 57 per cent of requests were approved (Di Matteo and Schoneveld 2016). Further details on trends in investment are discussed below.

\section{Interest in biofuels}

The interest in biofuel production, which formed an important part of broader interest in biofuels in Mozambique, took off in the mid-2000s. Around 13 per cent of all land investments between 2004 and 2009 went to biofuels and sugar investments (Terra Firma 2013, cited in Cabral and Norfolk 2016: 7). Analysis of the first wave of biofuel investments by Schut et al. (2010) revealed that much of the land requested for biofuels projects was in the relatively land-scarce south, with somewhat less demand in the north. In most provinces, requests for land were below 10 per cent of the total available land that had been identified through zoning. The main exception was for Maputo province, where 111 per cent of the available land was requested for biofuels projects. Of the 17 projects requested for biofuels, sugarcane, sweet sorghum, and cassava constituted the lion's share of ethanol investments (5 altogether). All biodiesel investments (12) aimed to use jatropha seeds. For biofuel investments in the study by Di Matteo and Schoneveld (2016), of 22 DUATs requested for biofuel projects, 10 approved projects covering an average area of 10,130 ha. Areas approved for biofuel investments are on average larger than other agricultural land uses with the exception of forestry, for which the area approved was 140,000 ha. 
In order both to regulate and potentially benefit from the interest in biofuels, the government of Mozambique introduced a series of policy measures and regulations on biofuels. In 2009, the biofuels policy and strategy was introduced, which stated that biofuel crop production must be planned according to agro-ecological mapping in order to avoid displacement of basic food crops production. The document also discouraged the use of staple food crops such as cassava and maize as biofuel feedstock. To generate domestic gains from biofuel production, in 2012 the government introduced bioethanol blending mandates at 10 per cent (i.e. E10 fuel), foreseeing that these may be met once production came online.

In 2014 the government introduced biofuels sustainability criteria, which set out further conditions for biofuels cultivation. The main clause is a requirement that investments should not impact local food security negatively and requires investors to provide evidence that they are following a plan to maintain access to basic food crops in the region compared to the situation before operations. The sustainability criteria, however, do not specify a minimum percentage of land that must be retained for food crop cultivation.

The interest in biofuels was perceived to generate positive outcomes given the state of the Mozambican rural economy at the time. A computable general equilibrium (CGE) modelling study on the benefits for biofuels by Arndt et al. (2010) concluded that biofuels could provide Mozambique with a substantial opportunity for growth and poverty reduction. Benefits would be shared more broadly if production resulted from outgrower-type models rather than from a vertically integrated estate model. A key determinant of the propensity to reduce poverty lies in the labour intensity of production.

\section{More recent developments in investment trends - 2011 onwards}

Recent research by the Land Matrix (Nolte et al. 2016) suggests that Mozambique remains an important destination for investment, although the amount of land listed as forming part of a deal and being under cultivation has fallen since reports in 2012. The Land Matrix's latest report (Nolte et al. 2016) lists only 500,000 ha covered by 65 concluded agricultural deals. Data is scarcer on the area actually under production, but the Land Matrix could confirm only 21,000 ha in production (Wise 2016). These include ambitious investment schemes premised on models of agricultural corridors such as the Nacala Corridor and Lurio River Development, which have generated substantial controversy in Mozambique.

\section{Siting of investments}

Reviews of recent projects suggest that the southern provinces (including Maputo and Gaza) continue to attract high levels of attention from investors due to good connections to infrastructure in Mozambique and close proximity to South Africa (especially from South African investors) but there is also considerable amount of investment in the central region (especially Manica), in part due to an influx of investors from Zimbabwe. Glover and Jones (2016) find that large farms favour areas that are peri-urban, or they cluster in areas where road and railway networks have been established.

A separate set of information comes from the IAI surveys, which includes a database of 'large' farms (over $50 \mathrm{ha}$ ) from each of the sampled districts. The 2012 survey round (which was analysed by Glover and Jones 2016) includes 156 farms of which 22 are in the north, 51 in the centre, and 83 in the south. Of the total, 102 are smaller than 1,000 ha, 44 are larger than 1,000 ha; and 8 are larger than 10,000 ha. ${ }^{3}$ Data from a recent IAI survey (Deininger and Xia 2016) for large farms

\footnotetext{
${ }^{3}$ As discussed below, the larger farms (above 10,000 ha) had a high proportion of fallow land.
} 
that were established or changed hands between 2012 and 2014 reveals that of the 419 large farms surveyed, the largest number (308) are in the southern provinces, followed by the central regions (94).

\section{Large areas of fallow land in investment sites}

Analysis of trends between 2002 and 2012 shows that, although the total area covered by large 'operating' farms grew by 206,700 ha from 235,800 ha in 2002 to 441,500 ha in 2012, around 187,300 ha (or 90 per cent) of the new land incorporated into large farms was (or became) unused or fallow - and the total amount of land that was fallow rose from 29 per cent in 2002 to reach 58 per cent in 2012. This was especially the case around Maputo and surrounding provinces in the south of the country (Glover and Jones 2016).

Further disaggregation of the large-farm data by Deininger and Xia (2016) suggests that farms larger than 1,000 ha have the highest proportion of fallow land (c. 65 per cent), and around 40 per cent of land occupied by farms larger than 5,000 ha is also unused (Figure 4).

Figure 4: Land use in different classes of farm size (2012)

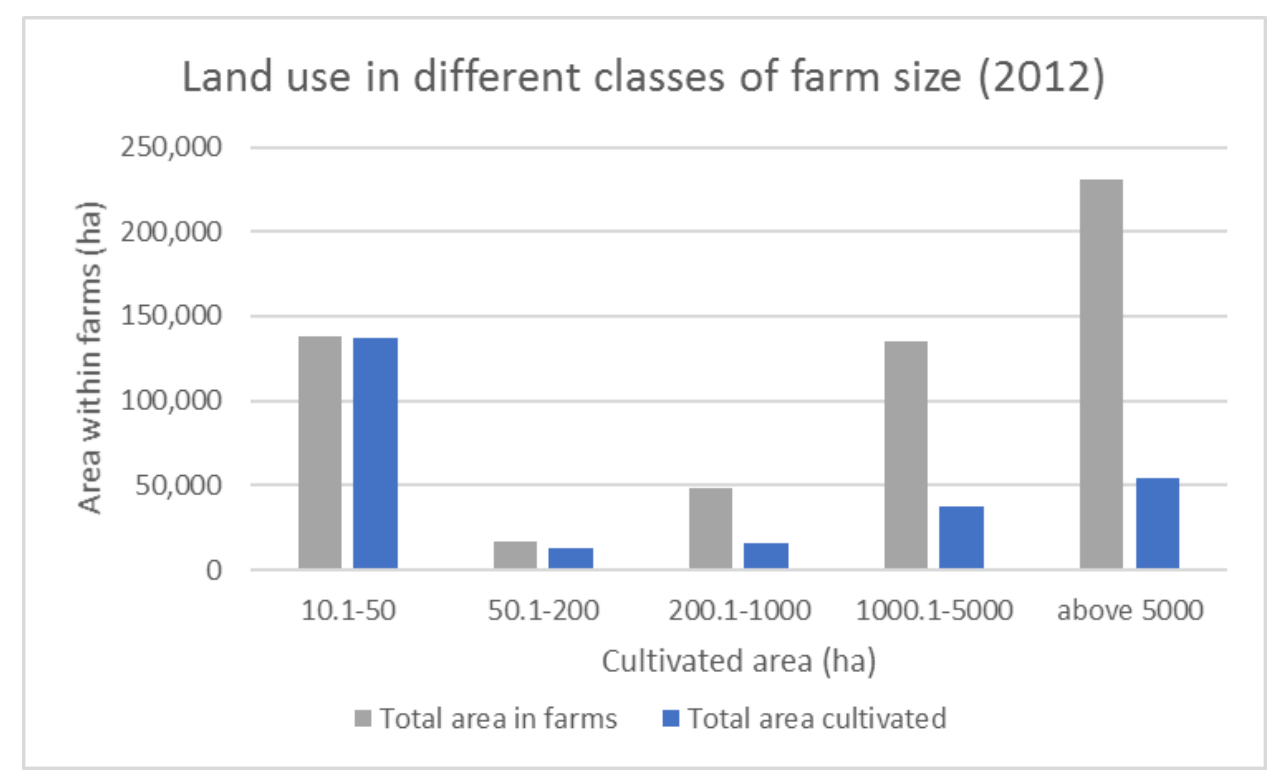

Note: For reasons of scale, farms of $0-10$ ha (covering 5.5 million ha) are not show on this graph. The proportion of fallow land on small farms is very low.

Source: Authors' calculation based on Deininger and Xia (2016).

\section{Large farms and sugarcane}

A large proportion of the 419 large farms cultivate sugarcane. In the central region, around 98 per cent of the land cultivated by large farms is planted to sugarcane, compared to around 71 per cent in the southern region, and 84 per cent overall. The average size of farms cultivating sugarcane is also much higher in the central region, at around 1,080 ha, compared to 71 ha in the southern region and 260 ha overall.

On average, yields of sugarcane cultivated on large farms are about three times higher than those that smallholders achieve. There are substantial differences between the three regions, with farms in the south achieving around 22,000 metric tonnes (MT)/ha while farms in central Mozambique achieving yields of around 19,300 MT/ha. Smallholder farms produce around one-third of this, with those in central Mozambique producing around 6,700 MT/ha while those in the south produce around 8,800 MT/ha. 


\section{Failure of biofuel projects}

Biofuel projects proved to have been built on shaky foundations. Data in the Land Matrix (Nolte et al. 2016) suggests that biofuels projects constitute the largest category of failed projects. Similarly, a recent review of a database of agriculture investments by Di Matteo and Schoneveld (2016) finds that around 85 per cent of biofuel investments that have been set up have subsequently ceased their operations: only 2 of 27 jatropha operations were operational in 2015 . A 2013 study (Atanassov 2013) revealed that major reasons for the cessation of activities, apart from the failure of jatropha as a crop, included the financial crisis which made capital scarce, and difficulties in getting licences (DUATs), which are necessary to attract investors to continue to finance projects.

\subsection{Land governance in Mozambique}

Mozambique is generally recognized to have one of the most progressive land laws in Africa. Although all land legally belongs to the state, the Land Law19/97 of 1997 safeguards the rights of citizens to land and natural resources by providing them the right to use and benefit from land with or without formal documentation. The national law also accommodates customary law over land, leaving decisions on matters of inheritance and land use to community-level institutions.

However, due to concerns that community land is at risk from large-scale acquisitions, both government and donors have supported efforts to increase the formal registration of landholdings and improve land information systems (Locke 2014). Over the last decade there has been a concerted effort to demarcate community-held land in order to provide a higher level of tenure security to communities. Data from 2003-16 suggests that around 2.1 million ha (or 2.7 per cent of the total territorial area) has been delimited as community land, and while the total area of registered land is unknown, it is estimated to be about 3-5 per cent of the total land held by communities (Cabral and Norfolk 2016; Locke 2014). Through delimitation, communities can demarcate up to 100,000 ha of land, subject to approval of the provincial governor.

For investors, although land cannot be alienated, a right to use and benefit from land (a DUAT) can be acquired through a 50-year lease. The process to acquire land requires sanction from the local administrative authorities, and a consultation with the communities to ensure that the area in question is free and unoccupied. The sanctioning authority depends on the size of the lease sought. When the request is for an area up to 1,000 ha, it requires only the approval of the provincial governor. When such requests are for areas between 1,000 ha and 10,000 ha, decisions are made in conjunction with relevant government departments at national level, but they may only be authorized by the Minister of Agriculture. And when a request is for more than 10,000 ha, the request has to be sent to the Council of Ministers for approval. In addition, companies are required to register a business plan with the state investment agency, the Centro de Promoção de Investimentos (CPI). While, in principle, the legal framework provides for close monitoring of investments to ensure they incorporate local consultation and are performing in line with their plans, in reality there are gaps in capacity which means investments are rarely monitored (Locke 2014). 


\section{$4 \quad$ Findings}

\subsection{Biophysical opportunities and constraints}

Areas suitable for sugarcane cultivation from a biophysical perspective

On the basis of analysis of climatic, soil, land-use, and soil data, the map in Figure 5 shows areas where sugarcane - the major biofuel feedstock candidate - can be produced. Dark green shows the area ideal for sugarcane production in Mozambique. The light green shows areas of moderate potential for sugarcane cropping and the yellow those with very low potential.

On the basis of this analysis (Table 1), around 61 per cent of Mozambique is unsuitable for sugarcane production; 9.2 per cent is marginally suitable; 25 per cent is moderately suitable and only 4 per cent is fully suitable.

Figure 5: Map of distribution of land suitable for sugarcane production

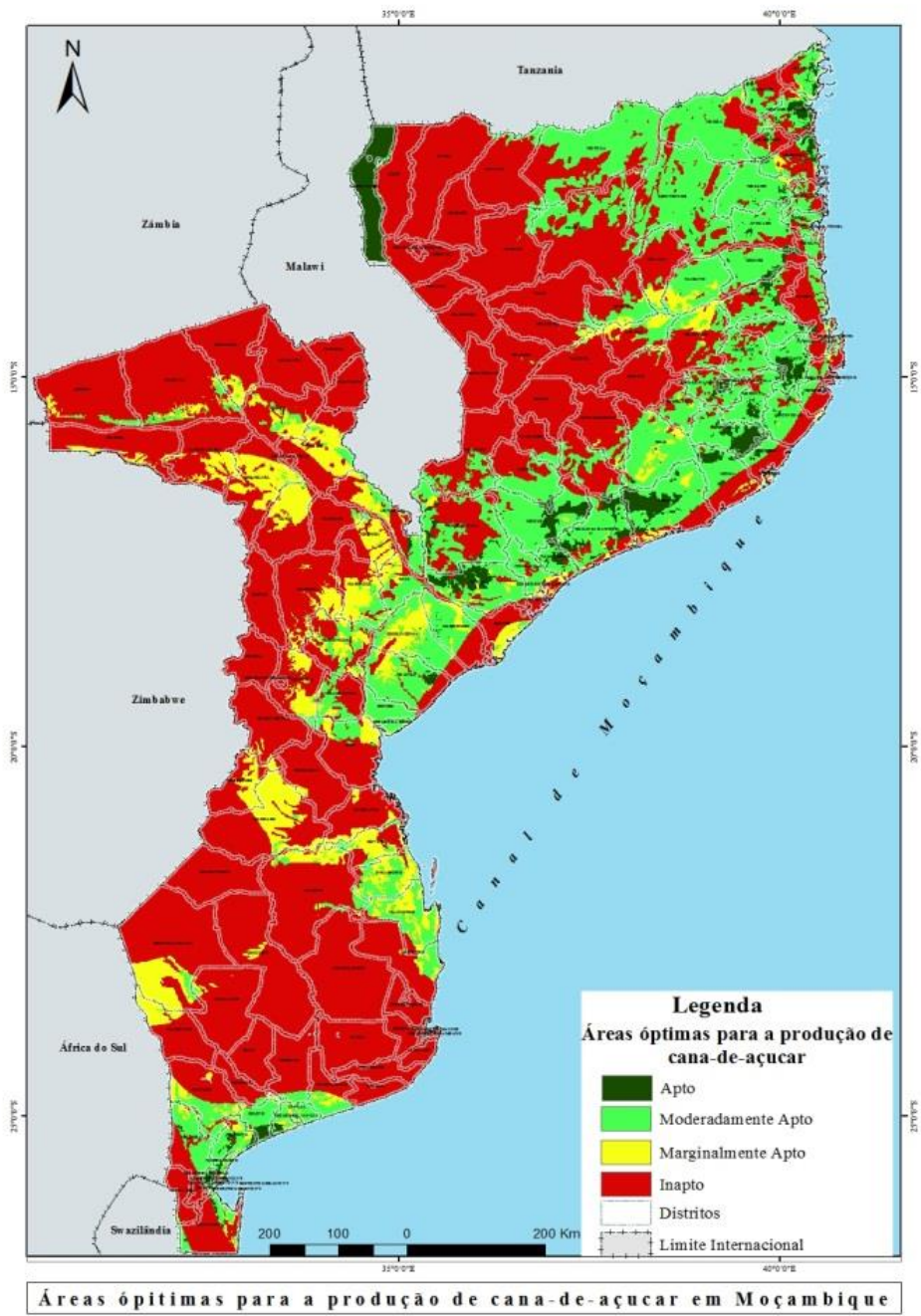

Source: Authors' compilation based on CENACARTA data. 
Table 1: Statistical results of classes suitable for sugarcane feedstock

\begin{tabular}{lccc}
\hline Categories of suitability & Area $\left(\mathrm{km}^{2}\right)$ & Areas $(\mathrm{ha})$ & Areas $(\%)$ \\
\hline Suitable & $\mathbf{3 1 , 4 8 7 . 3}$ & $\mathbf{3 , 1 4 8 , 7 3 4 . 9}$ & $\mathbf{3 . 9}$ \\
Moderately suitable & $199,689.2$ & $19,968,923.2$ & 25.0 \\
Less suitable & $73,592.4$ & $7,359,243.1$ & 9.2 \\
Unsuitable & $494,611.0$ & $49,461,101.2$ & 61.9 \\
Total & $\mathbf{7 9 9 , 3 8 0 . 0}$ & $\mathbf{7 9 , 9 3 8 , 0 0 2 . 3}$ & $\mathbf{1 0 0 . 0}$ \\
\hline
\end{tabular}

Sources: Authors' compilation based on CENACARTA data.

\section{Suitable districts in the southern region}

From Figure 5 it can be seen that the areas which have higher suitability for sugarcane feedstock production in the southern region include the districts of Manhiça, Marracuene, Moamba, Bilene, Xai-Xai, and Matutuine, and the districts with marginal and moderate suitability include Magude, Chokwé, Massingir, Mandlakaze, and most of Inhassoro, Govuro, Vilankulo, and Mabote districts. The rest are not suitable for sugarcane feedstock production in the southern Mozambique.

\section{Suitable districts in the central region}

In the central region of the country, most districts that are by the coast are suitable and moderately suitable for sugarcane feedstock production, including Mopeia, Mocuba, Namacurra, Pebane, and Maganja da Costa. In the district of Tete, the areas are marginally to moderately suitable along the Zambezi River Valley.

\section{Suitable districts in the northern region}

In the northern region the scenario is similar to the central region, where the suitable regions are localized in coastal districts, including the districts of Mogovolas, Monapo in Nampula region, and the districts of Macomia, Palma, and Mocímboa da Praia of the Cabo Delgado region. In Niassa region the most suitable districts are around the Niassa Lake and the districts of Majune and Lichinga, and a very few others, such as Mavago and Sanga, are also suitable.

\section{Water availability}

As sugarcane is a water-intensive crop, availability of water for irrigation is an important factor for considering feedstock expansion. As discussed below, yields of sugarcane grown under (usually commercial) irrigated conditions are three times higher than under rain-fed conditions and access to water and irrigation is therefore a major determinant for siting future production.

As Table 2 shows, Mozambique has around 118,000 ha equipped for irrigation, but only around 34 per cent of this area is actually irrigated. The province with the largest area equipped for irrigation is Gaza (50,323 ha), however only 8,825 ha is actually irrigated. 
Table 2: Statistics of irrigation areas in Mozambique

\begin{tabular}{lccc}
\hline Province & $\begin{array}{c}\text { Area equipped for } \\
\text { irrigation (ha) }(2010)\end{array}$ & $\begin{array}{c}\text { Area actually } \\
\text { irrigated (ha) } \\
(2001)\end{array}$ & $\begin{array}{c}\text { \% irrigated of area } \\
\text { equipped (2010) }\end{array}$ \\
\hline Gaza & 50,323 & 8,825 & 17.5 \\
Sofala & 24,220 & 13,850 & 57.2 \\
Maputo & 24,130 & 14,143 & 9.1 \\
Zambezia & 10,848 & 985 & 47.9 \\
Manica & 2,067 & 990 & 23.9 \\
Tete & 1,895 & 452 & 2.6 \\
Cabo Delgado & 1,764 & 45 & 13.8 \\
Inhambane & 1,285 & 177 & 62.2 \\
Nampula & 980 & 610 & 1.0 \\
Niassa & 608 & 6 & \\
Total & 118,120 & & \\
\hline
\end{tabular}

Source: FAO (2016).

The total area has remained unchanged since 2001, however rehabilitation has raised the amount irrigated from 4,000 ha in 2001 to 62,000 in 2010 (FAO 2016). The total area equipped is around 2 per cent of all cultivated land. Around 80 per cent of the irrigated area is in large schemes of over 500 ha. The largest use of irrigated land is for sugarcane, estimated at around 37,200 ha in 2010, or 60 per cent of all irrigated crops (FAO 2016).

The distribution of irrigated land by percentage of the landholding is shown in Table 3. Farms that are bigger than 100 ha (predominantly producing sugarcane) have 95 per cent of all irrigated land.

Table 3: Current irrigation areas by holding size and projection of future distribution

\begin{tabular}{|c|c|c|c|c|}
\hline \multirow[t]{2}{*}{ Classes } & \multicolumn{4}{|c|}{$\%$ of landholding } \\
\hline & Current situation (2015) & 2020 & 2025 & 2040 \\
\hline$<100$ ha & $4.4 \%$ & $5 \%$ & $7 \%$ & $10 \%$ \\
\hline $100-500$ ha & $20.6 \%$ & $21 \%$ & $30 \%$ & $40 \%$ \\
\hline$>500$ ha & $75.0 \%$ & $74 \%$ & $63 \%$ & $50 \%$ \\
\hline Total & $100.0 \%$ & $100 \%$ & $100 \%$ & $100 \%$ \\
\hline
\end{tabular}

Source: Ministry of Agriculture and Food Security (2015). 
According to a report by Mozambqiue's Ministry of Agriculture and Food Security (2015) there are eight river basins that have high irrigation potential. These are the Maputo, Limpopo, Búzi, Zambeze, Licungo, Melúli, Lúrio, and Rovuma river basins. Central Mozambique is the region with the highest irrigation potential (Zambezi basin), followed by north Mozambique (Rovuma, Lúrio), and then by south Mozambique (Melúli, Búzi, Limpopo, and Maputo).

Looking at suitable areas where irrigation could be expanded, several of the areas in the south that have suitable conditions for sugarcane production are also near to sources of water that meet irrigation needs. Magude district is drained by Incomati River and the Massingir and Macaretane dams along the Limpopo could service expansion of feedstock in Chokwe and Massingir districts. The planned Mapai and Moamba Major dams may also serve to increase the irrigable area of land in areas with good soils in surrounding areas. Since about 50 per cent of the areas of Mafambisse and Marromeu plantations is rain-fed, new irrigation infrastructure investment may be needed for rapid production expansion.

While water availability is a dominant concern, siting also needs to consider flooding risk, which can block access and undermine production, as occurred in several potential sites, including in Chokwe in 2000 and 2013, and Manhiça district more recently. For example, the Chokwe irrigation scheme in Gaza has in principle 23,000 ha of land that is irrigable but, due to flooding and salinization, the area that is actually irrigated is only 7,000 ha (Oates et al. 2015). Similarly, in Magude, although 2,200 ha is equipped with irrigation, only 450 ha is operational.

\subsection{Land availability: social aspects}

\section{Low population density}

As discussed in the introduction, the overall population density in Mozambique is low at around 30 inhabitants per square kilometre (statistics from GeoHive website). ${ }^{4}$ In rural parts of districts that are suitable for sugar production, the population density varies from 5 to around 90 inhabitants per square kilometre (see Table 4), but in districts with higher density such as Chokwe most households have smaller household plots (less than $0.5 \mathrm{ha}$ ) indicating that land for feedstock expansion should be available.

Table 4: Population density in research sites

\begin{tabular}{lc}
\hline District & Population density $\left(\right.$ inhabitants $\left./ \mathrm{km}^{2}\right)$ \\
\hline Magude & 9 \\
Chokwe & 88 \\
Massingir & 5 \\
Manhiça & 81.5 \\
\hline
\end{tabular}

Source: Population figures from Mozambique Institute of Statistics report at GeoHive website (2016).

However, looking at population data alone masks how much land is already under existing claim. It is therefore also important to consider issues around land availability by looking at the extent to which land rights have been clarified through exercises to delimit community lands.

\footnotetext{
${ }^{4}$ GeoHive website on Mozambique statistics: http://www.geohive.com/cntry/mozambique.aspx
} 
This process, which provides communities with a means to clarify the areas of land under their use, is also meant to serve as way to ensure that processes of identifying land for investment do not encroach on land needed for other uses. Although this provides information on where land may be claimed, there is substantial uncertainty over the area of land that has been delimited. While government figures suggest that around 21.2 million ha of land has been delimited across the country, the main sponsor of community land, the Iniciativa para Terras Comunitárias (ITC) reports that it has only delimited 5.4 million ha (Cabral and Norfolk 2016). The small proportion of land that has been delimited does not signal that non-delimited land is not subject to community claims. The reality is that a small proportion of communities have had their land delimited: Cabral and Norfolk (2016) note that government figures show that only 915 of an estimated 8,000-9,000 communities (or around 11 per cent) have had their land demarcated.

\section{Regional variation in demarcation progress}

Data from the National Directorate of Land and Forestry (DNTF) and its successor the National Directorate of Land (DINAT) on community delimitations up until 2014 suggest that there is considerable variation in the proportion of the province covered by community delimitation exercises, ranging from 60 per cent of Sofala to less than 10 per cent in Maputo (see Table 5 and Figure 6). Analysis by Di Matteo and Schoneveld (2016) of all DUATs issued in Nampula reveals that most DUATs are issued for community delimitation (53 per cent) followed by commercial agriculture (39 per cent).

From the point of view of responsible investment, it may be preferable to invest in those provinces where the proportion of area covered by delimitation is higher, as this suggests tenure rights are clearer, and there is less scope to depart from clear legal routes.

Table 5: Areas covered by DUATs issued for community delimitation across provinces

\begin{tabular}{lccc}
\hline Province & $\begin{array}{c}\text { Area (ha) covered by } \\
\text { DUATs }\end{array}$ & $\begin{array}{c}\text { No. of } \\
\text { communities }\end{array}$ & Average size (ha) \\
\hline $\begin{array}{l}\text { Cabo } \\
\text { Delgado }\end{array}$ & 623,382 & 66 & 9,445 \\
Gaza & $1,466,069$ & 106 & 13,831 \\
Inhambane & 679,292 & 24 & 28,304 \\
Manica & $1,366,013$ & 52 & 26,269 \\
Maputo & 211,597 & 30 & 7,053 \\
Nampula & $1,147,755$ & 145 & 7,916 \\
Niassa & $2,831,849$ & 154 & 18,389 \\
Sofala & $4,085,963$ & 62 & 65,903 \\
Tete & $4,030,219$ & 53 & 76,042 \\
Zambézia & $4,776,351$ & 223 & 21,419 \\
Total & $21,218,489$ & 915 & 23,190
\end{tabular}

Source: Data reported in Cabral and Norfolk (2016). 
Figure 6: Area covered by DUATs as a percentage of provincial land area

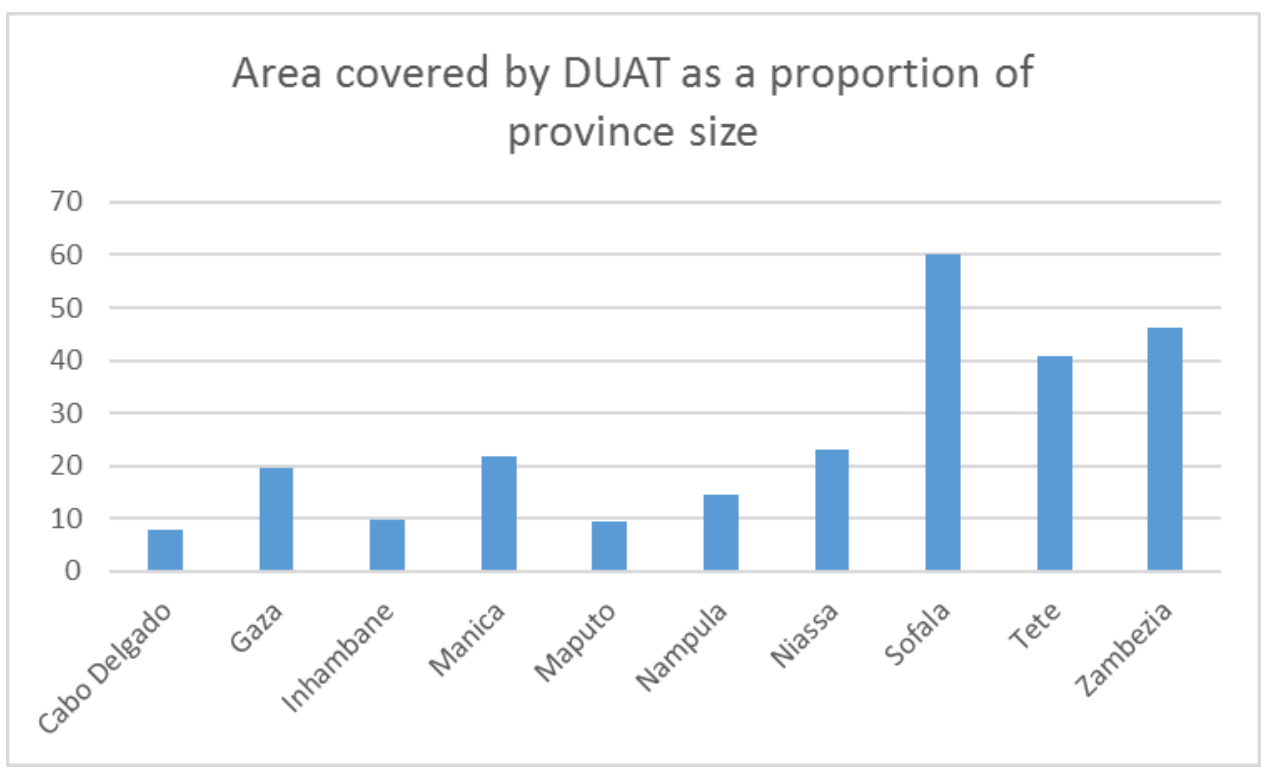

Source: National Directorate of Land (DINAT) data reported in Cabral and Norfolk (2016).

\subsection{Land availability: areas already attracting large amount of investment}

As discussed in the introduction, Mozambique has attracted substantial interest from investors over the past 15 years, and a large amount of land has already been granted to large-scale investors through DUATs issued by the government. Areas of interest for expanding sugarcane may therefore already face limitations if available land has already been taken up by existing investments. On the other hand, given the large amount of unused land reported in new investments, DUAT holders may be willing to transfer rights for unused land to existing investors.

Through mapping exercises, provincial-level departments of agriculture have also identified areas of land that are available for investment. As shown in Table 6, the areas of land for investment as a proportion of the size of the province varies. Provinces that have identified the largest areas of land for investment tend to be relatively large (Niassa) or sparsely populated (Inhambane), while more populated (Nampula) or smaller provinces have identified smaller areas of available land.

However, as shown in the fourth column of Table 6, the provinces with the largest available area of land are not necessarily those that have attracted the most investors. For example, although Tete has around 23 per cent of land available, it has attracted the fewest investors (10; equivalent to 2 per cent of all investors). Conversely, Maputo, which has the smallest area of land suitable for investment has attracted the largest numbers of investors. Di Matteo and Schoneveld (2016) note that reliable data to indicate if the area allocated exceeds the area of potentially suitable and available land does not exist, but that in the two provinces (Nampala and Zambezia) that have detailed data on DUATs, the area that has been granted through existing DUATs appears to occupy almost completely the area that the Ministry of Agriculture identifies as suitable and available for investment. For Zambezia, the area under DUATs for commercial agriculture is 679,886 ha, while the area considered suitable and available is 728,598 ha (93 per cent). For Nampula, the area under DUATs for commercial agriculture is 578,001 ha, while the area considered suitable and available is 592,744 ha (97 per cent). 
Table 6: Statistics of provincial-level land availability

\begin{tabular}{|c|c|c|c|c|c|}
\hline Province & $\begin{array}{l}\text { Surface area of } \\
\text { province (in ha) }\end{array}$ & $\begin{array}{c}\text { Suitable and } \\
\text { available land for } \\
\text { investment (in ha) }\end{array}$ & $\begin{array}{l}\text { Proportion of land } \\
\text { area available and } \\
\text { suitable for } \\
\text { investment }\end{array}$ & $\begin{array}{l}\text { Number of } \\
\text { investments }\end{array}$ & $\begin{array}{l}\text { Population } \\
\text { estimate } 2015 \\
\quad \text { (ranking) }\end{array}$ \\
\hline Tete & $10,066,225$ & $2,358,152$ & $23.4 \%$ & 10 & $2,517,444(3)$ \\
\hline Niassa & $12,958,020$ & $2,354,910$ & $18.2 \%$ & 20 & $1,656,906(8)$ \\
\hline Inhambane & $6,877,537$ & $1,863,206$ & $27.1 \%$ & 32 & $1,499,479(9)$ \\
\hline Manica & $6,228,724$ & 873,743 & $14.0 \%$ & 81 & $1,933,522(5)$ \\
\hline Zambezia & $10,313,290$ & 728,598 & $7.1 \%$ & 41 & $4,802,365(2)$ \\
\hline Gaza & $7,533,385$ & 628,937 & $8.3 \%$ & 56 & $1,416,810(10)$ \\
\hline Nampula & $7,813,213$ & 592,744 & $7.6 \%$ & 43 & $5,008,793(1)$ \\
\hline Sofala & $6,775,315$ & 575,973 & $8.5 \%$ & 46 & $2,048,676(4)$ \\
\hline Cabo Delgado & $7,785,097$ & 569,848 & $7.3 \%$ & 22 & $1,893,156(6)$ \\
\hline Maputo & $2,360,515$ & 11,000 & $0.5 \%$ & 127 & $1,933,522(7)$ \\
\hline Total & $78,711,321$ & $10,557,110$ & $13.4 \%$ & 478 & $24,486,209$ \\
\hline
\end{tabular}

Source: Data compiled by Di Matteo and Schoneveld (2016) from MINAG. Data in column 2 is from unpublished data from a Ministry of Agriculture zoning exercise.

While district-level information on farm size and land use of large farms is not available, looking at investments across different districts that are considered highly suitable for sugarcane production there is considerable variation, with some of the districts in the southern provinces hosting a relatively high number of investors, such as Marracuene (15) and Matutuine (13), whereas districts in the central and northern provinces have attracted fewer investors. It is therefore likely that the process of acquiring land in different districts varies, with governments in more popular destinations having a better understanding of investment procedures. There may also be more opportunities to acquire land already owned and partly developed by an investor. On the other hand, districts with no existing investment are likely to require investors to acquire greenfield sites, where counterparts in communities and governments may be less familiar with procedures for transferring land meaning the process is more difficult and is associated with a higher level of risk. 
Table 7: Comparison of districts with high potential for sugarcane cultivation and existing land investments

\begin{tabular}{|c|c|c|}
\hline Area & $\begin{array}{l}\text { Districts with high potential for } \\
\text { sugarcane cultivation }\end{array}$ & Number of existing investments \\
\hline \multirow[t]{5}{*}{ Southern } & Manhica & 9 \\
\hline & Marracuene & 15 \\
\hline & Bilene & 7 \\
\hline & Xai-Xai & 8 \\
\hline & Matutuine & 13 \\
\hline \multirow{5}{*}{$\begin{array}{l}\text { Zambezia } \\
\text { (central) }\end{array}$} & Mopeia & 1 \\
\hline & Mocuba & 7 \\
\hline & Namacurra & 1 \\
\hline & Pebane & 0 \\
\hline & Maganja da Costa & 2 \\
\hline \multirow[t]{2}{*}{ Nampula } & Mogovolas & 2 \\
\hline & Monapo & 5 \\
\hline \multirow[t]{3}{*}{ Cabo Delgado } & Macomia & 0 \\
\hline & Palma & 0 \\
\hline & Mocímboa da Praia & 0 \\
\hline \multirow[t]{2}{*}{ Niassa } & Majune & 7 \\
\hline & Lichinga & 4 \\
\hline
\end{tabular}

Source: Authors' compilation of data presented in Di Matteo and Schoneveld (2016).

\subsection{Access to land for agricultural investment}

Most, but not all, investors acquire land through DUATs. The survey by Di Matteo and Schoneveld (2016) reveals that the majority of investors accessed land through DUATs, but that around one-third of those acquiring land through DUATs received these from previous investors through transfer ('old' DUATs); the remainder were new DUATs.

However, around a quarter of investors with over 100 ha acquired land without a DUAT, either by renting ( 15.8 per cent) or by other customary arrangements ( 7 per cent). Those renting rented their land directly from communities, from state-owned facilities such as irrigation projects, or, in a small number of cases, by sub-leasing land from other commercial agricultural operations. Those acquiring land through customary access (usually local or national elites) did so through inheritance or through informal agreements with the community.

\subsection{Opportunities and constraints to accessing land for expansion through different channels}

The discussion above suggests that several channels are available for biofuel feedstock investors to acquire land in Mozambique. 
Channel 1: through developing greenfield sites by acquiring land either from government or communities. Although the process of acquiring land from the government is in theory more straightforward and predictable in terms of acquiring rights to land, recent research suggests that little land remains under government ownership which investors could lease (Dubb et al. 2016). Therefore, the main pathway to acquire land is through negotiating with communities.

Channel 2: by acquiring existing DUATs from current titleholders. As recent analysis discussed above suggests, there appear to be a large numbers of DUATs issued for land that is not under cultivation. Through either sub-leasing rights or the government taking back and re-issuing DUATs that do not comply with their conditions, this land could be assigned to investors seeking to plant sugarcane.

\section{Investment resulting from community land delimitation?}

The approach to encouraging investment through partnership with communities is a central thrust of the land legislation and subsequent community delimitation exercises. However, implementation of this approach has been slow, in part due to the fear that once land is identified as belonging to a community it will no longer be available for investment.

Even under the practices designed to promote win-win investment by delimiting community land and pairing investors with communities, there have been few examples of success (Cabral and Nofolk 2016). In some instances, the government's zoning exercises have equated areas of delimited community land as out of bounds for investment. In areas of high agricultural potential, local leaders have resisted using delimitation as a means of attracting investment. More commonly, the main barrier has been poor models for investor-community partnerships, with a lack of clarity over what institutional model fits best.

A central challenge to the concept of partnership models between communities and investors is the lack of a legal entity that can represent community members as joint owners of a right to community land. In some cases, government and investors identify traditional leaders as representatives, although these may not represent all interests equally. In others, other bodies such as the natural resource management committees (CGRNs) may be chosen by outside entities as representative, even though these have neither a legal identity nor accountability mechanisms (Cabral and Norfolk 2016).

\subsection{Social risks associated with biofuel expansion}

Potential displacement of economic activities

\section{Displacement and resettlement}

Under Mozambican law there is a clear division of responsibilities between the state, community, and company concerning the process of negotiating access to land and any subsequent compensation and resettlement required. However, the literature suggests there is significant variation of practice, with early experiences highlighting several cases where the process of consultation and gaining consent has not been consistent with the law or best practice.

A limited number of examples of resettlement exist in the agricultural sector. Accounts of less positive examples are provided in Smart and Hanlon (2015), who discuss broader challenges associated with the wave of land investments and how they have interacted with neighbouring communities. 
- In one example of a planned 10,000 ha soy bean farm (Hoyo Hoyo) the company did not follow the correct procedures. The vast majority of community members affected by the investment were not consulted, and the company moved onto land that was currently being use without prior agreement or warning. Displaced communities were not sufficiently compensated for lost assets, and social infrastructure the company had promised to put in place did not materialize. In addition, neither the government nor the company identified and allocated alternative land for displaced community members.

- In a second example of another soybean farming operation, 1,000 people were resettled through a process that did not include prior consultation with all affected households. The manner in which compensation was agreed was also unclear. Households in the resettled area did not have access to land of the same area, and faced food security problems (Mandamule 2016 cited in Cabral and Norfolk 2016).

- Recent experiences of population displacement to mobilize land for sugar cane production by Procana, a failed private sugar company, is still vivid in the memories of Mozambicans. Procana failed prematurely, but most people were not able to return to their previous land.

More broadly, findings from an investor survey (Di Matteo and Schoneveld 2016) suggest that, in around half of all investments (52 per cent), displacement of either farming activity or settlements occurred. Displacement was most prevalent when a new DUAT was acquired - these cases accounted for 86 per cent of all recorded displacements, and 83 per cent of cases of new DUATs being issued involved displacement. ${ }^{5}$ Cases of displacement were also common when land was rented from state-owned irrigation projects. Although displacement was reportedly less common when DUATs were acquired from former investors, it is likely that, in cases where land had been long-abandoned, displacement of encroached farmers was not reported.

Examples from the mining sector in Mozambique may also have lessons for agricultural investments. Although operating in different sectors, both have similar attributes of high levels of poverty and vulnerability, limited regulatory capacity, and pressure on land. Research looking at the impacts of the expansion of a mining operation in northern Mozambique found that the impacts had been both complex and highly disruptive on surrounding communities (Lillywhite et al. 2015).

The research found that the 3,600 people who were resettled were moved onto land that was more remote and less fertile than the land they were moved off, and had an insecure supply of water: the new location had no river to draw water from, and the soil in the new area required fertilizing to improve it to a point where crop productivity would be ensured. Particular deficiencies noted in the resettlement process included (Lillywhite et al. 2015):

- The contents of Resettlement Action Plans (RAPs) that companies produce did not address key categories of risk. This shortfall was not picked up by of the companies involved or by the government.

- RAPs risk becoming outdated as circumstances change. In one case investigated the total number of households affected by resettlement increased by 40 per cent as more information came to light on the programme's design, yet the RAP was not changed to reflect this.

- Approaches to address households' economic situations are inappropriate. In the case investigated, the Livelihood Restoration programme included several activities that were

${ }^{5}$ Di Matteo and Schoneveld (2016) note that under-reporting on conflict and displacement is likely, so these figures may under-represent incidence of displacement. 
structured on a cooperative model. This proved unsuitable to the local community, however, and once this failed it was not replaced.

- Conditions in sites of resettlement can be worse than in former villages, despite stated principles that this should not be the case. In the case reviewed, access to water in the new site was considerably worse than in the former site, and water became scarcer for human consumption, for irrigation, and for watering livestock. Despite recognition in the RAP that water was more scarce at the resettlement site, ensuring water was available was not included in the commitments of what the company should provide.

- Food security can be temporarily impaired while households resettle. Households were unable to easily start farming land in the area of resettlement due to their unfamiliarity with the soils and conditions. While the mining company provided food for free for a period, this ended before harvesting season.

- The new area had a much smaller economy, and lacked economic opportunities. Households lost access to off-farm sources of income, including brickmaking, quarrying, and charcoal selling. When estimating the burden on displaced households, the process ignored or under-estimated costs associated with transport as the new location was further away from local markets.

- Unclear communication resulted in households being uncertain about their eligibility to access different parts of the resettlement package.

\section{Heightened risks for women}

In addition to general risks associated with transferring and consolidating land that affect all households, this process tends to affect vulnerable households - including female-headed households more severely.

Women's ownership of land. Data from the CAP II survey (Cumbe and Diogo 2014) of small and medium agricultural survey across the whole of Mozambique suggests that overall women head around 27 per cent of all agricultural holdings. ${ }^{6}$ While the largest number of women-headed households have between 1 and 2 ha (36.4 per cent) - the same as for men - in general more female-headed households have smaller farms, while ownership of larger farms tends to be maleheaded. This has implications for possibilities to participate, as women are less likely than men to be able to join in outgrower schemes due to the small area of land they control.

Employment on plantations. Women are likely to face higher barriers in participating as labourers on commercial farms. In their study on recent investments in agriculture Di Matteo and Schoneveld (2016) find that women make up around one-third of farm employees on commercial farms surveyed. However, they also note that farms in the south of the country are more likely to employ women, as prevailing gender norms in the central and northern areas hinder participation.

\subsection{Benefits: jobs and spillovers}

The argument is often made that investments create spillovers for neighbouring households. Employment generation is one of the major projected benefits that is supposed to compensate for lost access to land. Based upon data analysed in Schut et al. (2010), biofuel investments were anticipated to provide $0.14-0.17$ jobs/ha, which was lower than levels investors had cited in their submissions. Di Matteo and Schoneveld (2016) find that, on average, investments provided 403

6

http://www.fao.org/fileadmin/templates/ess/documents/meetings_and_workshops/Gender_Expert_2014/Moza mbique_Presentation_Disaggregated_Data.pdf 
jobs (formal and casual). Less than third of jobs ( 29 per cent) created were formal with the remainder being formal. Around a third of workers (both formal and casual) were women.

\section{Conclusions}

This study discusses the potential for biofuel feedstock from several angles. Taking the case of sugarcane, it explores the potential to expand sugarcane production, through exploring both biophysical factors and patterns of existing investment. Central and northern Mozambique are more suitable for sugarcane growing. However, investors are preferring to grow it in south Mozambique. These regions have good infrastructure, which brings them closer to main international markets.

Sugarcane is grown by large farmers who have better infrastructure. Farmers who have more than 100 ha use 95 per cent of the existing irrigation infrastructure. Large areas of potentially irrigable land remain unirrigated as irrigation facilities have not been rehabilitated or kept up. There is potentially a strong case to develop these areas first. However, securing financing for this is likely to require investors to carry out similar due diligence processes on potential social impacts as if they were applying for new areas of land.

There are plans for significant investments in infrastructure, including irrigation, roads, rail, and ports in the next 15 to 20 years that are likely to have trickle-down effects in the economy. However, planning is deficient. Some major investment decisions in transportation infrastructure are not always part of an agreed national development master plan, which may lead to poor benefits to agricultural producers.

Analysis of the land sector suggests that land is much less abundant than was previously assumed, even in regions where population density is low. As registration of community land is an important process to avoid allocating community land to investors, it is important that further registration of community land should take place. While the registration of land for investment should, in theory, incorporate community consultation, there are often risks associated with this process if the process of consultation with community members is not inclusive.

Looking forward, land licensing, public consultations, better management of social responsibility, and provision of public goods in resettled areas all seem vital if sugarcane production is to be expanded in Mozambique. The current production system, based on smallholdings spread around the country, will have to change if sugar production is to expand to a significant scale. Existing outgrower schemes might serve as a model, but will have to be expanded to bring more land and better varieties into production. 


\section{References}

Arndt, C., R. Benfica, F. Tarp, J. Thurlow, and R. Uaiene (2010). 'Biofuels, Poverty, and Growth: A Computable General Equilibrium Analysis of Mozambique’. Environment and Development Economics, 15(01): 81-105.

Arndt, C., M.A. Hussain, E.S. Jones, V. Nhate, F. Tarp, and J. Thurlow (2012). 'Explaining the Evolution of Poverty: The Case of Mozambique'. American Journal of Agricultural Economics 94(4): 854-72.

Atanassov, B. (2013). The Status of Biofuels Projects in Mozambique. Background report for scoping report on biofuels projects in five developing countries. London: Overseas Development Institute.

Atanassov, B., G. Correia, and L. Machuama (2015). 'Food Security Impacts of Industrial Crop Expansion in Mozambique'. Policy and Practice Paper. London: Greenlight Energy and Overseas Development Institute.

Buur, L., C. Mondlane Tembe, and O. Baloi (2012). 'The White Gold: The Role of Government and State in Rehabilitating the Sugar Industry in Mozambique'. Journal of Development Studies 48(3): 349-62.

Cabral, L., and S. Norfolk (2016). 'Inclusive Land Governance in Mozambique: Good Law, Bad Politics?' IDS Working Paper 478. Brighton: Institute of Development Studies and Swiss Agency for Development and Cooperation.

Cumbe D., and D. Diogo (2014). 'Collecting Sex-disaggregated Data on Land Ownership and Management in Mozambique. Lessons from 2010 Agricultural Census and Annual Agricultural Surveys'. Available at: http://www.fao.org/fileadmin/templates/ess/documents/meetings_and_workshops/Gen der_Expert_2014/Mozambique_Presentation_Disaggregated_Data.pdf (accessed 4 January 2017).

Deininger, K., and F. Xia (2016). 'Quantifying Spillover Effects from Large Land-based Investment: The Case of Mozambique'. World Development 87: 227-41.

Di Matteo, F., and G.C. Schoneveld (2016). Agricultural Investments in Mozambique: An Analysis of Investment Trends, Business Models and Social and Environmental Conduct. Bogor, Indonesia: CIFOR.

Dubb, A., I. Scoones, and P. Woodhouse (2016). 'The Political Economy of Sugar in Southern Africa - Introduction'. Journal of Southern African Studies online: 1-24.

FAO (2016). AQUASTAT website. Food and Agriculture Organization of the United Nations. Available at: http://www.fao.org/nr/water/aquastat/data/query/index.html?lang=en (accessed 1 December 2016).

GeoHive (2016). Website on Mozambique statistics. Available at: http://www.geohive.com/cntry/mozambique.aspx (accessed January 2017).

Glover, S., and S. Jones (2016). 'Can Commercial Farming Promote Rural Dynamism in subSaharan Africa? Evidence from Mozambique'. WIDER Working Paper 2016/120. Helsinki: UNU-WIDER.

Government of Mozambique (2010). Multisectoral Plan for Chronic Malnutrition Reduction in Mozambique 2011-2014 (2020). Available at: http://www.who.int/nutrition/landscape_analysis/MozambiqueNationalstrategyreductions tunting.pdf (accessed February 2017). 
IIAM and DNTF (2008). Zoneamento Agrario - Resultados do exerccicio de validacao de resultados de terra disponivel a nwel local (fase 2). Maputo: IIAM and DNTF.

Lillywhite, S., D. Kemp, and K. Sturman (2015). Mining, Resettlement and Lost Liveliboods: Listening to the Voices of Resettled Communities in Mualadri, Mozambique. Melbourne: Oxfam.

Locke, A. (2014). 'Mozambique Land Policy Development Case Study'. Available at: http://www.evidenceondemand.info/mozambique-land-policy-development-case-study (accessed February 2017).

Ministry of Agriculture and Food Security (2015). Programa Nacional de Irrigação. Maputo: Instituto Nacional de Irrigação.

Nolte, K., W. Chamberlain, and M. Giger (2016). International Land Deals for Agriculture. Fresh Insights from the Land Matrix: Analytical Report II. Available at: http://www.landmatrix.org/media/filer_public/ab/c8/abc8b563-9d74-4a47-9548cb59e4809b4e/land_matrix_2016_analytical_report_draft_ii.pdf (accessed February 2017).

Oates N., G. Jobbins, B. Mosello, and J. Arnold (2015) 'Pathways for Irrigation Development in Africa - Insights from Ethiopia, Morocco and Mozambique'. Working Paper 119 Summary. Futures Agricultures Consortium. Brighton: University of Sussex. Available at: http://www.future-agricultures.org/publications/research-and-analysis/workingpapers/1957-pathways-for-irrigation-development-in-africa-insights-from-ethiopiamorocco-and-mozambique-summary/file (accessed November 2016).

Schut, M., M. Singerland, and A. Locke (2010). 'Biofuels Development in Mozambique: Update and Analysis of Policy, Potential and Reality'. Energy Policy, 38: 5151-65.

Smart T., and J. Hanlon (2013). Chickens and Beer: A Recipe for Agricultural Growth in Mozambique. Available at:

https://www.open.ac.uk/technology/mozambique/sites/www.open.ac.uk.technology.mozambi que/files/files/Chickens_and_beer-a_recipe_for_growth_in_Mozambique.pdf (accessed February 2017).

UNICEF (2016). Joint Child Malnutrition Estimates, 2016 edition. Available at: http:/ /data.unicef.org/topic/nutrition/malnutrition/ (accessed November 2016).

van der Hilst, F., and A.P.C. Faaij (2012). 'Spatiotemporal Cost-supply Curves for Bioenergy Production in Mozambique'. Biofuels Bioproducts and Biorefining, 6: 405-30.

van der Hilst, F., J.A. Verstegen, and A.P.C. Faaij (2012). “Go” and "No-go” Areas for Biomass Production in Mozambique Identified by Top Down Modeling and Bottom Up Data Gathering'. ECOWAS-GBEB Regional Biomass Resource Assessment workshop, Rome, 13 November. Available at:

http://www.globalbioenergy.org/fileadmin/user_upload/gbep/docs/2012_events/WGCB _Activity_1_Rome_13-14_November_2012/1.6_-_VAN_DER_HILST.pdf (accessed January 2016).

Wise, T. (2016). 'Land Grab Update: Mozambique Still in the Crosshairs'. GDAE Globalization Commentaries, 31 October. Medford, MA: Global Development and Environment Institute. 